Naamsestraat 61 | bus 3550

B-3000 Leuven | BELGIUM

Tel. 03216326661

vives@kuleuven.be

\title{
VIVES 2013
}

\section{DISCUSSION PAPER}

\section{8}

Do wages reflect labor productivity?

\section{The case of Belgian regions}

Jozef Konings \& Luca Marcolin

Joep.Konings@kuleuven.be \& Luca.Marcolin@kuleuven.be

May 2013

Copyright (C 2010 by K.U.LEUVEN, VIVES. Discussion papers are in draft form. This discussion paper is distributed for purposes of comment and discussion only. It may not be reproduced without permission of the copyright holder. 


\section{Non-technical summary}

Unemployment rates are significantly different across regions in Belgium. In the search for an explanation for this fact, we simultaneously estimate a wage and labor productivity equations where we include regional dummies as explanatory variables. We find that the wage-productivity gap reached $11 \%$ for Brussels and $4.2 \%$ for Wallonia in the years 2005-2012. This was driven by the negative performance in labor productivity of the firms in these regions relative to Flanders, which more than compensated for the advantage in unit labor costs they could profit from. On the other hand, the gap for Brussels is found to be currently decreasing in time thanks to a positive growth rate in labor productivity. The sign and magnitude of the wage-productivity gap is robust to the estimation of the relationship using hours worked instead of employees, and including benefits to salaries into the cost of labor.

These results are coherent with the existence at the regional level of institutional barriers to the firm-level adjustment of wages to labor productivity. Among the possible explanations for this, our estimations suggest that a reduction in the gap between labor costs and productivity may be achieved through greater wage flexibility at the regional level. 


\section{Introduction}

Classic economic theory applied to the labor market assumes that markets are perfectly informed and able to allocate workers in open vacancies in equilibrium. These workers are paid a salary equal to their marginal product of labor, since labor supply and demand are both satisfied. In the real world, however, this condition might not hold, as there exist many market frictions triggered by imperfect information and institutional factors, such as employment protection, unemployment benefits, collective bargaining, minimum wages and taxation. The persistently high unemployment rates plaguing the Western World, and Europe in particular in the aftermath of the Great Recession suggest that wage rigidity combined with falling productivity may be an important channel causing increasing unemployment. Belgium is no exception, with $7.6 \%$ national unemployment rate in 2012 averaging over the $17.4 \%$ unemployment rate of Brussels, the $4.5 \%$ rate of Flanders and the $10.0 \%$ rate of Wallonia (source: Eurostat).

The current study searches for an economic rationale for these persistent differences in unemployment across regions, and it does so by analyzing deviations in the evolution of wages and labor productivity for Brussels, Flanders and Wallonia. We will therefore estimate simultaneously a labor productivity function and a wage equation on Belgian firm level data, where we include indicators for the regional location of the firm as main explanatory variables. In this way, we also analyze the relative competitiveness of Belgian regions. Labor productivity growth is considered a key indicator to assess regional competitiveness, together with the increase in labor utilization and cost. These metrics are fundamental to the determination of the gains in living standards of regions over time, therefore they hold a prominent position on the policy makers' agenda at the European level. This ambition can be found in the EU2020 agenda, where it stats that Europe needs "a strategy to turn the EU into a smart, sustainable and inclusive economy delivering high levels of employment, productivity and social cohesion". Shortly below it is stated that the aim of the EU2020 strategy "is to create conditions for modernizing labor markets with a view to raising employment levels and ensuring the sustainability of our social models. This means empowering people through the acquisition of new skills to enable our current and future workforce to adapt to new conditions and potential career shifts, reduce unemployment and raise labor productivity".

Our results present evidence of stronger deviations between labor productivity and wages in Wallonia and Brussels relative to Flanders. While the average labor costs of firms in Wallonia and Brussels are lower than in Flanders, the gap between average labor costs and labor productivity is even larger. As a consequence, firms in Wallonia or Brussels have a competitive disadvantage compared to Flanders, although the gap seems to be narrowing in the last years for Brussels. 
The study is organized as follows: the first paragraph introduces short evidence on the labor market in Belgium and the theoretical framework we will exploit to interpret our results. A second paragraph follows commenting on the empirical methodology and the literature which proposed it. The third paragraph presents the data we exploit, the fourth the results of the econometric analysis. The conclusion follows.

\section{The institutional context}

Although unemployment in Belgium seems to be on a decreasing pattern down from the 2011 peak, mismatches between vacancies and available workforce have not substantially decreased in 2012 compared to 2007: almost half of the long term unemployed are still low or medium skilled, while $80 \%$ of vacancies search skilled workers (Zimmer 2012). This happens despite Belgium being among the highest spenders for labor market policies (LMP) in Europe: in 2010 (latest available data, source: Eurostat) it invested more than $3.7 \%$ of GDP in LMPs, ranking third in Europe after Spain and Denmark. It also ranked fourth from the top for expenditure in labor market services and sixth for out-of-work income maintenance and support. Such malfunctioning of Belgian labor market is also stressed in the OECD 2013 Economic Survey for Belgium, which states that "longstanding structural labor market problems remain, such as high structural unemployment, low employment rates for younger and older workers and for low-skilled and migrants, and large labor market mismatches".

Many have pointed to the role of labor market institutions as fundamental contributing factors to unemployment: the OECD 2011 Economic Survey for Belgium, for instance, reports that "co-ordinating policies to secure a smoother transition [from the crisis labor market equilibrium] is difficult, as the communities are responsible for education, the regions for employment and professional training, and the federal government for labor legislation, collective agreements and social security" ${ }^{11}$. The results of our estimation point at the existence of a regional component in the mismatch between labor cost and productivity in Belgium, which can be at least partially explained in the light of differences (or lack thereof) in labor market institutions across the regions.

Average productivity can of course differ across regions: Konings and Torfs (2011), for instance, show that agglomeration economies can explain important differences in productivity. Since economic activity is more concentrated in Flanders than in Wallonia for example, it is likely that agglomeration economies (such as inputoutput linkages, knowledge spillovers and labor market pooling) are more important in Flanders than in Wallonia, resulting in higher productivity in the former. In order to

\footnotetext{
${ }^{1}$ Ever since 2011, the competence of the regional governments on labor market policies has been strengthened. For instance, regions are now responsible for the interview process which evaluates the unemployed person's job search effort, as well as for the sanctions which may apply as a consequence.
} 
match these regional differences in labor productivity, wages should also adjust on a regional level to obtain full employment. This is easily explained with the aid of a standard labor market equilibrium graph, such as Figure 1.

Figure 1: Labor supply and demand equilibria with rigid wages for Wallonia and Flanders.

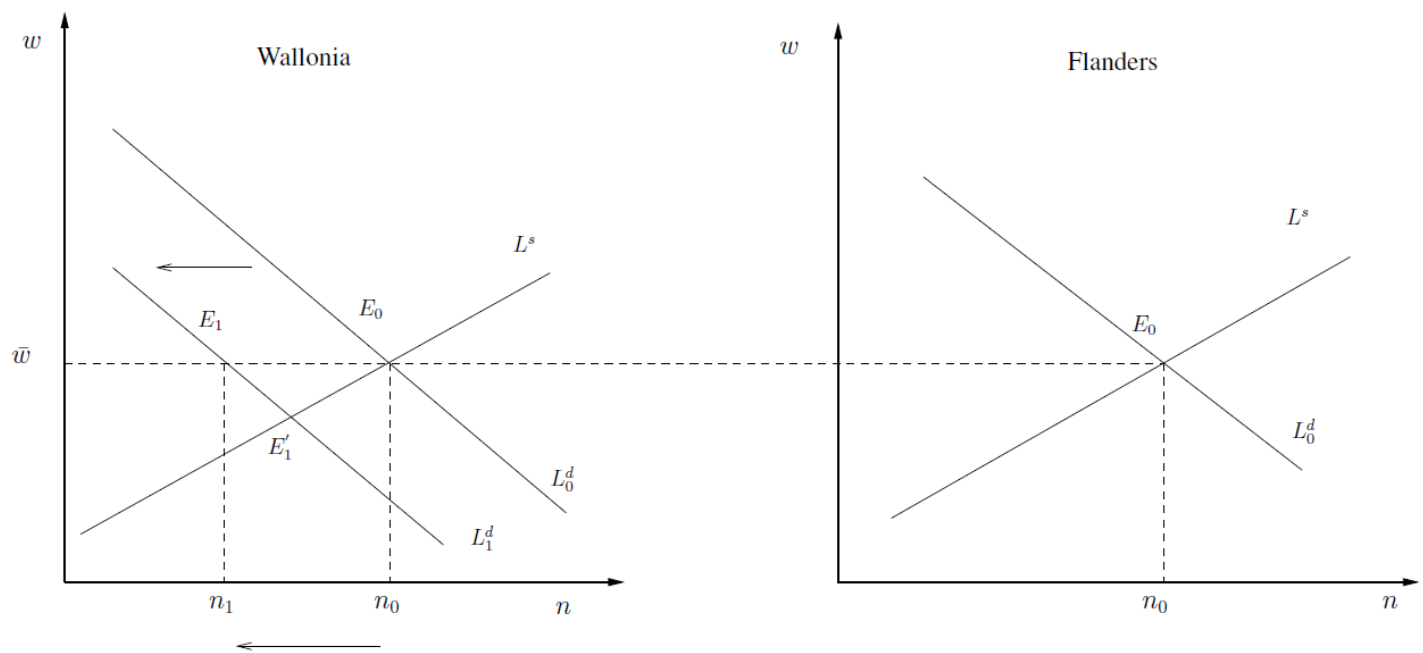

Figure 1 models two regional labor market equilibria with common wage setting. If the negotiation process yields the same average wage for a given industry $(\bar{w})$ across both regions, an asymmetric negative shock in the labor demand hitting one region but not the other translates in the creation of unemployment in the region hit by the shock $\left(n_{0}-n_{1}\right)$. Here Wallonia is depicted as hit by the shock in the light of what happened in the Great Recession in recent years. When the region is hit by the economic shock, the labor demand curve shifts downwards; return to full employment (equilibrium $E_{1}^{\prime}$ ) through a decrease in equilibrium wage is impeded by the existence of the nation-wide bargained wage rate $\bar{w}$ for the sector. The labor market reaches the equilibrium with unemployment $E_{1}$, where labor supply and demand schedule do not meet.

The graph therefore suggests that fixing a nation- (sector-) wide wage may be an important contributing factor in the reported existence of unemployment in Belgium. This puts in a regional perspective what the OECD 2013 Economic Survey for Belgium highlights, i.e. that "the highly coordinated wage formation process preserves relative wage differentials, implying that wages do not reflect emerging differences in relative labor demand and thus contribute relatively little to support ongoing reallocation of labor". In the next paragraphs we try to substantiate the existence of regional mismatches in labor market in Belgium by estimating the gap between labor productivity and unit labor costs. 


\section{The empirical framework}

We approach the analysis of the effectiveness of Belgian regional labor markets by estimating a value added per worker function and a wage equation at the firm level; the main regressors of interest are dummy variables for the location of the firm in Flanders, Wallonia or the Brussels region. The estimating equations hence read:

$\log \left(\frac{\text { Value Added }}{n}\right)_{i j t}=\alpha_{0}+\alpha_{1} D_{i j t}^{B X}+\alpha_{2} D_{i j t}^{W A}+\alpha_{3} \log (\text { Age })_{i j t}+\alpha_{4}$ Size $_{i j t}+\varphi_{j}+\theta_{t}+\varepsilon_{i j t}$

$\log \left(\frac{\text { Wage Bill }}{n}\right)_{i j t}=\gamma_{0}+\gamma_{1} D_{i j t}^{B X}+\gamma_{2} D_{i j t}^{W A}+\gamma_{3} \log (\text { Age })_{i j t}+\gamma_{4}$ Size $_{i j t}+\varphi_{j}+\theta_{t}+\eta_{i j t}$

where the dependent variable of (1) is labor productivity (or value added per employee) of firm " $i$ " in sector " $j$ " in year " $t$ ", while the dependent variable of (2) is average firm wage. $D_{i j t}^{B X}$ and $D_{i j t}^{W A}$ are the dummies for Brussels and Wallonia identifying where the firm is located (the dummy for Flanders is correctly removed to avoid perfect multicollinearity). Age stands for the period past from the year of firm establishment to the reporting year, while Size is a proxy for firm's size and will be specified in the estimation as ; they are both are be important determinants of firms' performance and costs. Finally, specific sectors and specific years may have an impact on both labor productivity and unit labor costs: to net out our results from such influence, we include industry $\left(\varphi_{\mathrm{j}}\right)$ and year $\left(\theta_{\mathrm{t}}\right)$ fixed effects. $\varepsilon_{\mathrm{ijt}}$ and $\eta_{\mathrm{ijt}}$ are idiosyncratic errors.

We first estimate equations (1) and (2) with OLS and clustered errors to account for firm heterogeneity. This provides us with an intuition of the direction in the discrepancy (if any) between labor productivity and unit labor costs due to the regional location of firms. Our estimators are unbiased if we assume that the establishment of a firm's in a specific region is exogenous to the firm's productivity and unit labor costs; in other words if firms do not self-select into locating in a specific region due to their productivity or unit labor cost. We argue that this assumption may hold in the case for the location choice between Flanders and Wallonia or Brussels in light of the existence of the linguistic and cultural barriers, as it happens for workers flows. On this respect see, for instance, Persyn \& Torfs (2012), who found regional borders effects on the commuting flows across Belgian regions. Since there is no variation over time in the location of firms across regions, estimating equations (1)-(2) with OLS exploits between-firm variation in order to identify productivity and wage premia.

Simple OLS, however, does not permit to explicitly test whether the coefficient of the regional dummy is equal between equation (1) and (2), as the two equations are estimated on different samples and for different outcome variables. That is why we add a third estimating equation, where the dependent variable is the difference of the dependent variables in equations (1) and (2): 
$\log \left(\frac{\text { Value Added }}{\text { Wage Bill }}\right)_{i j t}=\pi_{0}+\pi_{1} D_{i j t}^{B X}+\pi_{2} D_{i j t}^{W A}+\pi_{3} \log (\text { Age })_{i j t}+\pi_{4}$ Size $_{i j t}+\varphi_{j}+\theta_{t}+\epsilon_{i j t}$

What is more, we restrict the sample to the same number of observations across the three estimating equations, so that $\pi_{1}=\alpha_{1}-\gamma_{1}$ and $\pi_{2}=\alpha_{2}-\gamma_{2}$. If $\pi_{1}$ and $\pi_{2}$ resulted significantly equal to zero, the hypothesis of equality of coefficients across value added and wage cost equations would be validated. In what follows, we will often refer to the dependent variable of model (3) as competitiveness, as it stands for the value added produced with one unit of labor costs. This measure is also adopted as a proxy for internal competitiveness by the European Commission ${ }^{2}$.

This methodology for testing the significance of the wage-productivity gap at the firm level was introduced by Van Ours \& Stoeldraijer (2011). Since then, several works have adopted it: e.g. Cataldi, Kampelmann \& Rycx (2011), Garnero \& Rycx (2013), and Vandenberghe $(2013)^{3}$. Before the innovative paper by Van Ours \& Stoeldraijer (2011), the literature did not consider eq(3), but rather analyzed the mismatch between labor productivity and wages by jointly estimating the productivity and wage equations, either by transforming the data (e.g. the seminal paper by Hellerstein, Neumark \& Troske (1999)), or by using seemingly unrelated regressions (SUR), as in Van Biesebroeck $(2007,2010)$. This econometric technique helps in estimating systems of two or more equations representing relationships which are linked one with each other, i.e. when the errors are correlated across equations in the system (Zellner (1962), Fiebig (2001)). By simultaneously estimating the two (or more) equations, SUR consistently estimates the errors' covariance matrix, thus permitting cross-equation comparison of coefficients. As a consequence, we also find convenient to estimate (1) (3) with SUR, which yields a Feasible GLS estimator, and test the hypothesis that no mismatch is present, i.e. $\alpha_{1}=\gamma_{1}$ and $\alpha_{2}=\gamma_{2}$.

We run the three just mentioned estimation techniques (OLS, OLS on the restricted sample, SUR) using different specifications of the outcome variables. In particular, the number of full time equivalent employees ( $n$ ) in equations (1)-(3) is substituted by the average number of employees working for the firm, and by the number of hours worked by full time equivalent employees. The latter is a common feature in the labor economics literature, where hours worked are considered a more precise account of the labor input contribution to production. A fourth specification includes workers' benefits and compensations into the wage bill, which can also be considered part of labor costs.

\footnotetext{
${ }^{2}$ It corresponds to real unit labor costs. European Competitiveness Report (2009), European Commission.

${ }^{3}$ An important difference between the current study and the cited research is the choice of determinants which are included in the estimating equations. The quoted papers investigate the impact of workers' characteristics (age, education, gender) or their dispersion on labor productivity and costs, and they do so by exploited firm level information on the composition of the labor force. We do not have access to such information hence a similar analysis is precluded.
} 


\section{Data \& Descriptive Statistics}

We work on firm level data obtained from the Bureau Van Dijk product for Belgium (Belfirst). The dataset covers the population of Belgian firms and the reporting quality is high. We exploit both accounting data (turnover, value added, cost of intermediate inputs) and social balance sheet information (number of full, full time equivalent and part time employees, wage bill and compensations by category, hours worked). We retrieve data from all operating firms in the years 2005-2012. After some cleaning, we are left with 518,758 firm (or 430,544 firms on average per year), 59\% of which was located in Flanders, $24 \%$ in Wallonia and $17 \%$ in Brussels (ref. Table 1).

Table 1: Size of the sample by region.

\begin{tabular}{lccc}
\hline & $\begin{array}{c}\text { Number of } \\
\text { firms }\end{array}$ & $\begin{array}{c}\text { \% Number of } \\
\text { firms }\end{array}$ & $\begin{array}{c}\text { Number of } \\
\text { observations }\end{array}$ \\
\hline FL & 305,534 & 58.9 & $2,020,564$ \\
WA & 126,528 & 24.39 & 839,687 \\
BX & 86,696 & 16.71 & 584,104 \\
Total & 518,758 & & $3,444,355$ \\
\hline
\end{tabular}

Notes: "Number of firms" is to be intended as the number of firms which appear at least once in the datasets.

Table 2 contains summary statistics for the sample which will be used to estimate our regressions. From a first glance to the data it emerges that Flanders have a higher value added per unit of labor cost (our measure of competitiveness) than Wallonia and Brussels ${ }^{4}$. This is due mainly to the better performance of Flanders in terms of average labor productivity (i.e. value added per worker), which is coherent with previous evidence (Konings \& Marcolin 2011) ${ }^{5}$, despite the high unit labor costs (higher than in the other regions).

\footnotetext{
${ }^{4}$ We discuss here descriptive statistics in level to ease the interpretation. The estimations, however, will be carried out in logarithm. Interpreting descriptive statistics in logarithm is in fact not immediate, hence their omission here. ${ }^{5}$ The number of observations per year may differ from Table 1 to Table 2 since some of the firms reported in Table 1 have missing values for some variables of interest. In particular, many firms in the sample do not report any employee, while our analysis focuses on firms with at least one employee.
} 
Table 2: Variables of interest, averages over all years (2005-2012).

(All variables are expressed in '000 EUR, except for number of employees).

\begin{tabular}{|c|c|c|c|c|c|c|}
\hline & & count & mean & sd & $\min$ & $\max$ \\
\hline \multirow[t]{6}{*}{ Flanders } & Value added & 259532 & 1117.04 & 10660.60 & 0 & 1664001 \\
\hline & Wage bill & 259532 & 681.50 & 5567.46 & 1 & 570587 \\
\hline & Number of employees & 259532 & 14.69 & 116.66 & 1 & 13353 \\
\hline & Labor productivity & 259532 & 81.94 & 59.56 & 0 & 475.29 \\
\hline & Average wage (ulc) & 259532 & 37.75 & 16.10 & 0 & 106.35 \\
\hline & Competitiveness & 259532 & 2.39 & 1.95 & 0 & 17 \\
\hline \multirow[t]{6}{*}{ Wallonia } & Value added & 109574 & 876.74 & 12927.49 & 0 & 2822272 \\
\hline & Wage bill & 109574 & 536.85 & 4430.72 & 1 & 595290 \\
\hline & Number of employees & 109574 & 12.67 & 84.65 & 1 & 11125 \\
\hline & Labor productivity & 109574 & 66.65 & 49.56 & 0 & 475 \\
\hline & Average wage (ulc) & 109574 & 32.47 & 14.75 & 0 & 106.27 \\
\hline & Competitiveness & 109574 & 2.29 & 1.89 & 0 & 17 \\
\hline \multirow[t]{6}{*}{ Brussels } & Value added & 48426 & 2658.26 & 37493.63 & 0 & 2766212 \\
\hline & Wage bill & 48426 & 1615.62 & 21974.47 & 1 & 1394097 \\
\hline & Number of employees & 48426 & 32.08 & 471.72 & 1 & 34565 \\
\hline & Labor productivity & 48426 & 71.52 & 59.67 & 0 & 475.38 \\
\hline & Average wage (ulc) & 48426 & 37.13 & 19.07 & 0 & 106.36 \\
\hline & Competitiveness & 48426 & 2.13 & 1.87 & 0 & 17 \\
\hline \multirow[t]{6}{*}{ Total } & Value added & 417532 & 1232.73 & 16667.86 & 0 & 2822272 \\
\hline & Wage bill & 417532 & 751.88 & 8973.54 & 1 & 1394097 \\
\hline & Number of employees & 417532 & 16.17 & 190.22 & 1 & 34565 \\
\hline & Labor productivity & 417532 & 76.72 & 57.53 & 0 & 475.38 \\
\hline & Average wage (ulc) & 417532 & 36.30 & 16.30 & 0 & 106.36 \\
\hline & Competitiveness & 417532 & 2.34 & 1.93 & 0 & 17 \\
\hline
\end{tabular}

The described sample is reported in Figures 2 to 4 as well, where each graph displays the trend in either average labor productivity, unit labor costs and their ratio. Brussels and Wallonia score worse than Flanders in productivity over all the years in the sample, while Brussels unit labor costs are comparable to the Flemish ones. This reflects in a striking negative performance of Brussels relative to the other regions in the sample (ref. Figure 4). On the other hand, in the latest years the trends in labor productivity seem to suggest a slowing down in the rate of growth for Flanders, thus 
permitting Wallonia and Brussels to catch up with the region in terms of value added per unit of labor cost. We now turn to the econometric analysis to estimate which of these descriptive facts are confirmed by a more rigorous assessment of the data.

Figures 2, 3, 4: Trends in average outcome variables (2005-2012).
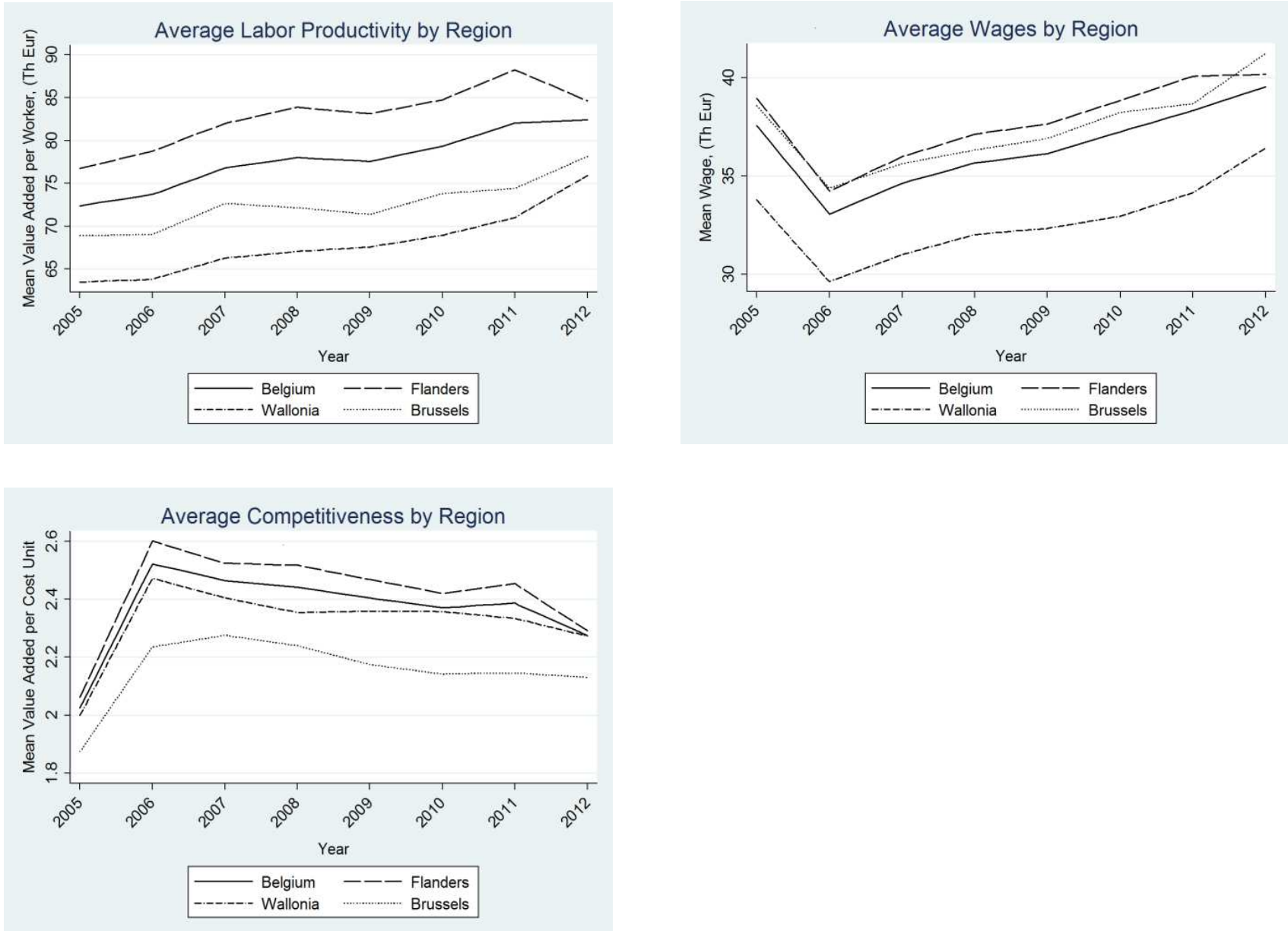

\section{Regression Analysis}

Table 3 reports the results of the estimated regressions where information on full time equivalent employees has been exploited. $B x$ and $W a$ represent the dummies for the location of a firm in the Brussels and Wallonia region, respectively. All results for the regional dummies, as a consequence, need to be interpreted in relative terms to Flanders. Size2-Size4 are dummies for the size of the firm, respectively for small firms (i.e with more than 10 employees and less than 51), medium (more than 50 and less than 251) and big (more than 250) firms. The excluded category are then micro firms 
(10 employees or less), hence all results should be interpreted in relative terms to this category $^{6}$. The dependent variable for each model is specified in the header of the columns. Results are presented for the three estimation techniques presented in the previous paragraph: OLS with clustered errors, OLS with clustered errors where the sample is restricted to have the same number of observations for the three different outcome variables, and seemingly unrelated regressions. All estimations include year and industry fixed effects, so as to net the coefficients of interest from time trends and industry specificities. We therefore implicitly compare firms which have identical features except for their location.

The three different econometric specifications yield coherent results ${ }^{7}$. All coefficients are highly significant across the three specifications. The last two rows of the table report the signs and magnitudes for the elasticities obtained from the regional dummies. $\mathrm{EL}(\mathrm{Bx})$ (resp. $\mathrm{EL}(\mathrm{Wa})$ ) is the computed elasticity of the outcome variable to being located in Brussels (resp. Wallonia) rather than Flanders. Halvorsen \& Palmquist (1980) proved that these elasticities need to be computed from the estimated coefficients according to the following transformation:

$$
E L(X)=e^{\beta_{X}}-1
$$

where $\left(\beta_{X}\right)$ is the estimated coefficient for the regional dummy $X=\{B x ; W a\}$. Our regressions indicate that, everything else held constant, firms located in Brussels and Wallonia rather than Flanders benefit of a discount in unit labor cost of approximately $5 \%$ and $13.5 \%$ respectively. On the other hand, they also suffer from a substantial disadvantage in labor productivity ranging from $16 \%$ to $17 \%$ for Brussels and Wallonia. As a consequence, the wage-productivity gap of these regions with respect to Flanders is significant and equal to $11 \%$ for Brussels and $4.2 \%$ for Wallonia for 2005-12, conditional on our other controls. This is equivalent to say that the gap between the wage and productivity premium associated with firm's location is almost three time as big in Brussels than in Wallonia.

Interpreting the relative magnitude of coefficients of regional dummies across different models is possible thanks to the seemingly unrelated regressions (Zellner (1962)). We hence tested for the equality of the coefficient of the dummy for Brussels (resp. Wallonia) across the productivity and wage equations. The null hypothesis is always strongly rejected at $1 \%$ value $e^{8}$. Standard errors are bootstrapped to take into account heterogeneity in the errors.

Finally, Table 3 highlights that a $1 \%$ increase in the age of the firm improves the firm's ratio of value added to total labor costs by $0.5 \%$. This happens thanks to a

\footnotetext{
${ }^{6}$ We also ran regressions using the log of size as a control instead of size dummies. Our conclusions are robust to this estimation as well.

${ }^{7}$ The coefficients of OLS(re) and SUR, in particular, are equal by construction, as in both estimations the sample is equally restricted. The computed standard errors, however, are different.

${ }^{8}$ Test statistics and $\mathrm{p}$-values are available upon request.
} 
productivity premium to age which exceeds the cost burden of being relatively established firms in the market. In other words, the longer a firm has been operating, the higher its average wage bill will be (due, for instance, to the presence of internal labor markets), but also its productivity. The reverse is true for size: being bigger corporations can impose a gap between labor costs and productivity by $24 \%$ to $29 \%$, depending on the size category ${ }^{9}$.

We check the validity of our results by estimating the same models as in $\mathrm{Eq}(1)$ (3) but exploiting a different information set (Table A(I) in the appendix). Columns a1a3 are estimated using the firm's average number of employees rather than the full time equivalent number of them, and the average cost of employees. Columns $b 1-b 3$ deflates both value added and total wage bill by the number of hours worked by full time equivalent employees rather than the number of employees. Finally, columns c1c3 are estimated adding workers' benefits and compensations to the wage bill, but once again using the number of full time equivalent employees to generate unit labor costs and labor productivity. To be synthetic, we present here only results obtained from the complete sample (OLS) and from SUR on the restricted sample ${ }^{10}$.

Results are coherent with the estimation using full time equivalent employees: Brussels and Wallonia enjoy a discount in unit labor costs and hourly labor costs with respect to Flanders of approximately $5 \%$ for Brussels and 12 to $13 \%$ for Wallonia, conditional on all other firm characteristics we control for. However, the labor productivity disadvantage is lower than the cost advantage for the regions, suggesting that workers in both regions relative to Flanders are overpaid. The wage-productivity gap is hence positive ${ }^{11}$ and reaches 4 to $7 \%$ for Wallonia relative to Flanders, and 11 to $15 \%$ for Brussels.

Signs are mostly coherent with previous specifications also for the age and size of the firm. An increase in both parameters yields an increase in the average unit labor cost for the firm; age, however, also increases labor productivity, contrary to size. Consequently, the productivity-wage gap is generally positively affected by an increase in firm's age (except when we run our estimation using worked hours) and negatively affected by an increase in firm's size.

\footnotetext{
${ }^{9}$ The exact magnitude of these gains is inferred from the calculation of elasticities such as in the case of regional dummies (not reported).

${ }^{10}$ Precise comparison of coefficients in models using averages, hours and benefits is not possible, because the reported regressions are run over different sample sizes, hence each model estimates separate variance/covariance matrixes and standard errors. The same holds for comparison of the columns estimated with OLS and SUR. As mentioned in the main body of the text, comparisons of magnitude in coefficients of labor productivity, unit labor costs and their ratio are on the contrary possible, for the columns estimated with SUR using the same data (e.g. columns 2, 8 and 14).

${ }^{11}$ The gap is expressed in terms of Productivity over Wages, hence the reverse than the wage-productivity gap..
} 
Table 3 : Regressions results for Full Time Equivalent Employees 2005-2012.

\begin{tabular}{|c|c|c|c|c|c|c|c|c|c|}
\hline VARIABLES & $\begin{array}{c}(a) \\
\text { LogULC }\end{array}$ & $\begin{array}{l}\text { OLS } \\
\text { (b) } \\
\text { LogLP }\end{array}$ & $\begin{array}{c}(c) \\
\text { LogGAP }\end{array}$ & $\begin{array}{c}(d) \\
\text { LogULC }\end{array}$ & $\begin{array}{c}\text { OLS(re) } \\
(\mathrm{e}) \\
\text { LogLP }\end{array}$ & $\begin{array}{c}(f) \\
\text { LogGAP }\end{array}$ & $\begin{array}{c}(\mathrm{g}) \\
\text { LogULC }\end{array}$ & $\begin{array}{c}\text { SUR } \\
(h) \\
\text { LogLP }\end{array}$ & $\begin{array}{c}\text { (i) } \\
\text { LogGAP }\end{array}$ \\
\hline$B x$ & $\begin{array}{l}-0.0521^{\star * *} \\
(0.00381)\end{array}$ & $\begin{array}{l}-0.172^{* * *} \\
(0.00499)\end{array}$ & $\begin{array}{l}-0.117^{\star \star \star} \\
(0.00416)\end{array}$ & $\begin{array}{c}-0.0518^{\star \star *} \\
(0.00381)\end{array}$ & $\begin{array}{l}-0.168^{\star * *} \\
(0.00500)\end{array}$ & $\begin{array}{l}-0.117^{\star \star \star} \\
(0.00416)\end{array}$ & $\begin{array}{l}-0.0518^{* * *} \\
(0.00262)\end{array}$ & $\begin{array}{l}-0.168^{\star \star \star} \\
(0.00305)\end{array}$ & $\begin{array}{l}-0.117^{\star * *} \\
(0.00231)\end{array}$ \\
\hline$W a$ & $\begin{array}{l}-0.145^{\star * *} \\
(0.00253)\end{array}$ & $\begin{array}{l}-0.189^{\star \star *} \\
(0.00330)\end{array}$ & $\begin{array}{l}-0.0431^{* * *} \\
(0.00288)\end{array}$ & $\begin{array}{l}-0.145^{\star * *} \\
(0.00253)\end{array}$ & $\begin{array}{l}-0.188^{* * *} \\
(0.00330)\end{array}$ & $\begin{array}{l}-0.0431^{* * *} \\
(0.00288)\end{array}$ & $\begin{array}{l}-0.145^{\star * *} \\
(0.00165)\end{array}$ & $\begin{array}{l}-0.188^{\star * *} \\
(0.00238)\end{array}$ & $\begin{array}{c}-0.0431^{* * *} \\
(0.00216)\end{array}$ \\
\hline Logage & $\begin{array}{l}0.0399^{* * *} \\
(0.00112)\end{array}$ & $\begin{array}{l}0.0453^{* * *} \\
(0.00148)\end{array}$ & $\begin{array}{c}0.00509^{* * *} \\
(0.00131)\end{array}$ & $\begin{array}{l}0.0396^{* * *} \\
(0.00112)\end{array}$ & $\begin{array}{l}0.0447^{* \star *} \\
(0.00148)\end{array}$ & $\begin{array}{c}0.00509^{\star * *} \\
(0.00131)\end{array}$ & $\begin{array}{c}0.0396^{* * *} \\
(0.000943)\end{array}$ & $\begin{array}{l}0.0447^{* * *} \\
(0.00128)\end{array}$ & $\begin{array}{c}0.00509^{* * *} \\
(0.00120)\end{array}$ \\
\hline Size2 & $\begin{array}{c}0.208^{* * *} \\
(0.00245)\end{array}$ & $\begin{array}{l}-0.0692^{* * *} \\
(0.00351)\end{array}$ & $\begin{array}{l}-0.278^{\star \star \star} \\
(0.00283)\end{array}$ & $\begin{array}{c}0.208^{* \star *} \\
(0.00245)\end{array}$ & $\begin{array}{l}-0.0702^{\star \star *} \\
(0.00351)\end{array}$ & $\begin{array}{l}-0.278^{\star \star \star} \\
(0.00283)\end{array}$ & $\begin{array}{c}0.208^{\star * *} \\
(0.00162)\end{array}$ & $\begin{array}{c}-0.0702^{\star \star \star} \\
(0.00235)\end{array}$ & $\begin{array}{l}-0.278^{* * *} \\
(0.00197)\end{array}$ \\
\hline Size3 & $\begin{array}{c}0.305^{\star * *} \\
(0.00482)\end{array}$ & $\begin{array}{l}-0.0182^{* *} \\
(0.00708)\end{array}$ & $\begin{array}{l}-0.323^{\star * *} \\
(0.00521)\end{array}$ & $\begin{array}{c}0.305^{\star * *} \\
(0.00480)\end{array}$ & $\begin{array}{l}-0.0177^{* *} \\
(0.00706)\end{array}$ & $\begin{array}{l}-0.323^{\star \star \star} \\
(0.00521)\end{array}$ & $\begin{array}{c}0.305^{\star * *} \\
(0.00308)\end{array}$ & $\begin{array}{l}-0.0177^{* * *} \\
(0.00391)\end{array}$ & $\begin{array}{l}-0.323^{\star * *} \\
(0.00346)\end{array}$ \\
\hline Size4 & $\begin{array}{l}0.369^{* * *} \\
(0.0111)\end{array}$ & $\begin{array}{c}0.0124 \\
(0.0177)\end{array}$ & $\begin{array}{l}-0.352^{* * *} \\
(0.0122)\end{array}$ & $\begin{array}{l}0.370^{\star * *} \\
(0.0109)\end{array}$ & $\begin{array}{c}0.0182 \\
(0.0172)\end{array}$ & $\begin{array}{l}-0.352^{\star \star \star} \\
(0.0122)\end{array}$ & $\begin{array}{c}0.370^{* * *} \\
(0.00809)\end{array}$ & $\begin{array}{c}0.0182 \\
(0.0116)\end{array}$ & $\begin{array}{l}-0.352^{\star \star \star} \\
(0.00858)\end{array}$ \\
\hline Year FE & Yes & Yes & Yes & Yes & Yes & Yes & Yes & Yes & Yes \\
\hline Industry FE & Yes & Yes & Yes & Yes & Yes & Yes & Yes & Yes & Yes \\
\hline Obs & 410702 & 414670 & 410324 & 410324 & 410324 & 410324 & 410324 & 410324 & 410324 \\
\hline EL(Bx) & -0.051 & -0.158 & -0.110 & -0.050 & -0.155 & -0.110 & -0.050 & -0.155 & -0.110 \\
\hline$E L(W a)$ & -0.135 & -0.173 & -0.042 & -0.135 & -0.171 & -0.042 & -0.135 & -0.171 & -0.042 \\
\hline
\end{tabular}

Notes:

Robust standard errors in parentheses for OLS and OLS(re). Bootstrapped standard erros for SUR.

$* * * \mathrm{p}<0.01, * * \mathrm{p}<0.05, * \mathrm{p}<0.1$ 


\section{Dynamics}

The picture of relative performance of Belgian regions partially changes when taking into considerations the growth rate of labor productivity and unit labor costs. We explore this venue to conform to the current policy debate, which seems to prefer comparisons across administrative units based on the rate of growth more than on the level of competitiveness. Higher productivity growth is indeed generally associated to a higher economy-wide growth rate, coherently with a neoclassical model of endogenous growth (Lucas(1988), Romer(1994)).

We therefore estimate equation (1)-(3) again, where the dependent variables become the year-on-year change in the logarithm of unit labor costs, labor productivity, and their difference. Table 4 shows the results of the estimations for the complete sample and for the sample where the same number of observations is exploited for the three regressions. In the baseline estimation the wage-productivity gap is reduced by the localization of the firm in Brussels but not Wallonia. This result is driven by the rate of productivity growth, which is higher for the former than the latter and higher than the coefficient for the cost growth equation, which is then reflected in a positive and significant coefficient for the dummy of Brussels but not Wallonia. It remains true, however, that being located in either Wallonia or Brussels increases the rate of growth of wages the firm is asked to pay to its workers more than a firm located in Flanders. The coefficients for age and size of the firm, on the other hand, seem to go in the same direction as reported in the estimation in levels: keeping every other firm's characteristics constant, an older or bigger firm displayed a lower yearly rate of growth in the ratio of productivity and wages between 2005 and 2012.

Our results in the preferred specification therefore suggest that a catching up process may be happening in Belgium in terms of regional productivity. Being located outside Flanders in the sample years guaranteed a greater rate of growth of productivity, no matter the cost performance. This translates in a positive coefficient for the productivity-wage gap but only for Brussels, while the coefficient for Wallonia is insignificant due to the important contribution of unit labor costs.

The results are rather robust when turning to different measures of the outcome variables. In Table $A(\mathrm{II})^{12}$, the evidence of the full time equivalent specification is strongly confirmed with respect to Brussels. As far as Wallonia is concerned, on the other hand, the sign of the coefficient for the wage-productivity gap turns from insignificant (for the full time equivalent sample, and here when including workers' benefits (column c3)) to negative and significant at 1 or $10 \%$ (columns a3 and $b 3$ ). The latter specification, however, reveals that firms located in Wallonia might experience a higher growth of labor costs than in Flanders, which may compensate the higher labor productivity growth, thus cancelling any significant effect on the rate of change in the wage-productivity gap. Evidence of a trend in the reduction of wage-productivity gap for Wallonia relative to Flanders is therefore somewhat mixed, but not for Brussels,

\footnotetext{
${ }^{12}$ Table A(II) , for simplicity, only reports the results using the restricted sample (OLS(re)). The complete set of results is available upon request.
} 
where our results portrait a less negative picture of the region's relative standing than suggested by the estimations in levels.

Table 4 : Growth Rates for Full Time Equivalent Employees 2005-2012.

\begin{tabular}{|c|c|c|c|c|c|c|}
\hline VARIABLES & $\begin{array}{c}(\mathrm{a}) \\
\Delta \operatorname{LogULC}\end{array}$ & $\begin{array}{c}\text { OLS } \\
\text { (b) } \\
\Delta \text { LogLP }\end{array}$ & $\begin{array}{c}(\mathrm{C}) \\
\Delta \text { LogGAP }\end{array}$ & $\begin{array}{c}(\mathrm{d}) \\
\Delta \text { LogULC }\end{array}$ & $\begin{array}{c}\text { OLS(re) } \\
(\mathrm{e}) \\
\Delta \text { LogLP } \\
\end{array}$ & $\begin{array}{c}(f) \\
\Delta \text { LogGAP }\end{array}$ \\
\hline$B x$ & $\begin{array}{c}0.00839 * * * \\
(0.00195)\end{array}$ & $\begin{array}{l}0.0283^{\star * \star} \\
(0.00265)\end{array}$ & $\begin{array}{l}0.0191^{\text {***}} \\
(0.00251)\end{array}$ & $\begin{array}{c}0.00857^{* * *} \\
(0.00195)\end{array}$ & $\begin{array}{l}0.0277^{\star * \star} \\
(0.00265)\end{array}$ & $\begin{array}{l}0.0191^{\star * *} \\
(0.00251)\end{array}$ \\
\hline$W a$ & $\begin{array}{c}0.00989 * * * \\
(0.00139)\end{array}$ & $\begin{array}{c}0.00864^{* * *} \\
(0.00173)\end{array}$ & $\begin{array}{l}-0.00134 \\
(0.00162)\end{array}$ & $\begin{array}{l}0.00994^{\star * *} \\
(0.00139)\end{array}$ & $\begin{array}{c}0.00860^{\star * *} \\
(0.00174)\end{array}$ & $\begin{array}{l}-0.00134 \\
(0.00162)\end{array}$ \\
\hline Logage & $\begin{array}{l}-0.0106^{* * *} \\
(0.000818)\end{array}$ & $\begin{array}{l}-0.0468^{* * *} \\
(0.00107)\end{array}$ & $\begin{array}{l}-0.0357^{* * *} \\
(0.000980)\end{array}$ & $\begin{array}{l}-0.0105^{\star \star *} \\
(0.000817)\end{array}$ & $\begin{array}{l}-0.0462^{\star \star \star} \\
(0.00107)\end{array}$ & $\begin{array}{l}-0.0357^{* * *} \\
(0.000980)\end{array}$ \\
\hline Size2 & $\begin{array}{l}0.0108^{* * *} \\
(0.00110)\end{array}$ & $\begin{array}{l}-0.0342^{\star * \star} \\
(0.00155)\end{array}$ & $\begin{array}{l}-0.0447^{* * *} \\
(0.00142)\end{array}$ & $\begin{array}{l}0.0107^{\star * *} \\
(0.00110)\end{array}$ & $\begin{array}{l}-0.0339^{* * *} \\
(0.00156)\end{array}$ & $\begin{array}{l}-0.0447^{\star \star \star} \\
(0.00142)\end{array}$ \\
\hline Size3 & $\begin{array}{l}0.0171^{* \star *} \\
(0.00188)\end{array}$ & $\begin{array}{l}-0.0289^{* * *} \\
(0.00277)\end{array}$ & $\begin{array}{l}-0.0462^{* * *} \\
(0.00248)\end{array}$ & $\begin{array}{l}0.0174^{\star * *} \\
(0.00186)\end{array}$ & $\begin{array}{l}-0.0288^{\star * *} \\
(0.00277)\end{array}$ & $\begin{array}{l}-0.0462^{\star * *} \\
(0.00248)\end{array}$ \\
\hline Size4 & $\begin{array}{l}0.0167^{\star \star *} \\
(0.00267)\end{array}$ & $\begin{array}{l}-0.0192^{\star * \star} \\
(0.00556)\end{array}$ & $\begin{array}{c}-0.0360^{\star \star *} \\
(0.00525)\end{array}$ & $\begin{array}{l}0.0168^{\star \star \star} \\
(0.00268)\end{array}$ & $\begin{array}{l}-0.0192^{\star \star \star} \\
(0.00557)\end{array}$ & $\begin{array}{l}-0.0360^{\star \star *} \\
(0.00525)\end{array}$ \\
\hline $\begin{array}{l}\text { Year FE } \\
\text { Industry FE } \\
\text { Obs }\end{array}$ & $\begin{array}{c}\text { Yes } \\
\text { Yes } \\
228950\end{array}$ & $\begin{array}{c}\text { Yes } \\
\text { Yes } \\
231117 \\
\end{array}$ & $\begin{array}{c}\text { Yes } \\
\text { Yes } \\
228692 \\
\end{array}$ & $\begin{array}{c}\text { Yes } \\
\text { Yes } \\
228692\end{array}$ & $\begin{array}{c}\text { Yes } \\
\text { Yes } \\
228692 \\
\end{array}$ & $\begin{array}{c}\text { Yes } \\
\text { Yes } \\
228692 \\
\end{array}$ \\
\hline $\begin{array}{l}E L(B x) \\
E L(W a)\end{array}$ & $\begin{array}{l}0.0084 \\
0.0099\end{array}$ & $\begin{array}{l}0.0287 \\
0.0087\end{array}$ & $\begin{array}{c}0.0193 \\
-0.0013\end{array}$ & $\begin{array}{l}0.0086 \\
0.0100\end{array}$ & $\begin{array}{l}0.0281 \\
0.0086\end{array}$ & $\begin{array}{r}0.0193 \\
-0.0013\end{array}$ \\
\hline
\end{tabular}

Notes:

OLS(re) is the specification where the sample is restricted to the same number of observations per each outcome variable (columns (d)-(f)).

Robust standard errors in parentheses.

${ }^{* * *} p<0.01,{ }^{* *} p<0.05,{ }^{*} p<0.1$ 


\section{Conclusions}

This study aimed at assessing whether there existed an equality in wage and labor productivity premia for firms in Brussels or Wallonia rather than Flanders. Our question stemmed from evidence of academic and policy making nature suggesting that regional labor market institutions influence the matching process of workers with vacancies. We therefore estimated a value-added-per-worker and a wage equation using firm level data for the population of Belgian firms. Our results suggest that even controlling for sector effects we still find important regional differences in wages and productivity, and that in Wallonia and Brussels wages seem to be "too high" compared to labor productivity. This reflects in a positive and significant wage-productivity gap for firms in Brussels and Wallonia with respect to Flanders. On the other hand, we see that labor productivity fell in 2012 in Flanders more than in Wallonia and Brussels. As a consequence the results of the estimation in growth of labor productivity and unit labor costs highlight that a process of convergence in productivity may be happening for both Brussels and Wallonia, although for Wallonia this is still not enough to reverse the trend in the productivity-wage gap.

Reducing unemployment and hence re-aligning wages with the worker's marginal product of labor requires an intervention on labor market institutions in Belgium. We argue that how our results can be interpreted in the light of the existence of collective agreements which apply to all firms operating within the same sector across all regions in Belgium. One possible field for action would therefore be represented by the wage bargaining process, which could be reformed towards a greater attention to regional specificities in labor productivity. 


\section{Bibliography}

Cataldi, A., Kampelmann,S. \& Rycx, F.(2011): "Productivity-Wage Gaps Among Age Groups: Does the ICT Environment Matter?". De Economist.

European Commission (2009): "European Competitiveness Report 2009", the European Commission

Eurostat (2010): "Labour market policy - expenditure and participants - Data 2010" . Eurostat Statistical Books

Fiebig, D. G. (2001): Seemingly Unrelated Regression, in Baltagi, B. eds, "A Companion to Theoretical Econometrics".

Garnero,A. \& Rycx,F.(2013): "The heterogeneous effects of workforce diversity on productivity, wages and profits". CEB Working Paper No 13/015.

Griffith, R., Redding,S. \& van Reenen, J. (2004): "Mapping the two faces of R\&D: Productivity Growth in a Panel of OECD Industries", Review of Economics and Statistics..

Halvorsen,R. \& Palmquist, R.(1980): "The Interpretation of Dummy Variables in Semilogarithmic Equations". The American Economic Review.

Hellerstein, J. K., Neumark,D. \& Troske, K.R.(1999): "Wages, Productivity, and Worker Characteristics: Evidence from Plant-level Production Functions and Wage Equations". Journal of Labor Economics.

Konings J., \& Marcolin L. (2011): "The competitiveness of regions: a comparison between Belgian and German regions". Review of Business and Economics.

OECD (2001): "OECD Productivity Manual: A Guide to the Measurement of Industry-Level and Aggregate Productivity Growth", OECD .

OECD (2011): "OECD Economic Surveys: Belgium". OECD

OECD (2013): "OECD Economic Surveys: Belgium". OECD

O'Mahony, M. \& Timmer, M.(2009): "Output, Input and Productivity Measures at the Industry Level: The EU KLEMS Database", The Economic Journal..

Persyn, D. \& Torfs, W. (2012) : "A Gravity Equation for Commuting". Vives DP33.

Romer, P. M. (1994): "The Origins of Endogenous Growth". The Journal of Economic Perspectives

Lucas, R. E. (1988). "On the mechanics of Economic Development". Journal of Monetary Economics.

van Ark, B. (1996): "Issues in Measurement and International Comparison Issues of Productivity - An Overview", Groningen Growth and Development Center. 
Van Biesebroeck J. (2007) "Wage and productivity premiums in sub-Saharan Africa", NBER WP.

Van Biesebroeck J. (2011): "Wages equal productivity. Fact or fiction?". World Development van Ours, J. \& Stoeldraijer, L (2011): "Age, Wage and Productivity in Dutch Manufacturing". De Economist.

Vandenberghe, V. 2013. "Are Firms Willing to Employ a Greying and Feminizing Workforce?". Labour Economics.

Zellner A. (1962): "An Efficient Method of Estimating Seemingly Unrelated Regression Equations and Tests of Aggregation Bias". Journal of the American Statistical Association.

Zimmer, H. (2012): "Labour market mismatches", Economic Review, National Bank of Belgium. 
APPENDIX

Table A(I) : Robustness Checks for outcome variables in levels 2005-2012.

\begin{tabular}{|c|c|c|c|c|c|c|c|c|c|c|c|c|c|c|c|c|c|c|}
\hline & \multirow{2}{*}{\multicolumn{2}{|c|}{$\begin{array}{l}\text { (a1) } \\
\text { (ava) }\end{array}$}} & \multicolumn{2}{|c|}{ (b1) } & \multicolumn{2}{|c|}{ (c1) } & \multicolumn{2}{|c|}{ (a2) } & \multicolumn{2}{|c|}{ (b2) } & \multicolumn{2}{|c|}{ (c2) } & \multicolumn{2}{|c|}{ (a3) } & \multicolumn{2}{|c|}{ (b3) } & \multicolumn{2}{|c|}{ (c3) } \\
\hline & & & & hour) & & nefits) & & avg) & & nour) & (ben & nefits) & & avg) & & our) & & nefits) \\
\hline & (OLS) & (SUR) & (OLS) & (SUR) & (OLS) & (SUR) & (OLS) & (SUR) & (OLS) & (SUR) & (OLS) & (SUR) & (OLS) & (SUR) & (OLS) & (SUR) & (OLS) & (SUR) \\
\hline & LogULC & LogULC & LogULC & LogULC & LogULC & LogULC & LogLP & LogLP & LogLP & LogLP & LogLP & LogLP & LogGAP & LogGAP & LogGAP & LogGAP & LogGAP & LogGAP \\
\hline$B x$ & $-0.0426^{\star \star \star}$ & $-0.0421^{\star \star \star}$ & * $-0.0460^{\star \star \star}$ & * $-0.0459^{\star * \star}$ & $-0.0518^{\star \star \star}$ & ${ }^{*}-0.0514^{\star * \star}$ & $-0.176^{\star \star \star}$ & $-0.176^{\star \star \star}$ & $-0.217^{\star \star \star}$ & $-0.210^{\star \star \star}$ & $-0.172^{\star \star \star}$ & $-0.168^{\star \star \star}$ & $-0.134^{\star \star \star}$ & $-0.134^{\star \star \star}$ & $-0.164^{\star \star \star}$ & $-0.164^{\star \star \star}$ & $-0.117^{\star \star \star}$ & $-0.117^{\star \star \star}$ \\
\hline & '(0.00384) & $(0.00287)$ & $"(0.00336)$ & $"(0.00235)$ & $(0.00381)$ & ' $(0.00253)$ & $(0.00501)$ & '(0.00309) & $(0.00606)$ & ) $)^{\prime}(0.00386)$ & ' $(0.00499)$ & ${ }^{\prime}(0.00315)$ & $(0.00417)$ & '(0.00249) & "(0.00554) & "(0.00397) & $(0.00416)$ & $"(0.00282)$ \\
\hline Wa & $-0.137^{\star * *}$ & $-0.136^{\star * *}$ & $-0.126^{* * *}$ & $-0.126^{* * *}$ & $-0.145^{\star \star \star}$ & $-0.144^{* * *}$ & $-0.193^{* * *}$ & $-0.192^{* * *}$ & $-0.204^{\star * *}$ & $-0.203^{* * *}$ & $-0.189^{\star * *}$ & $-0.188^{\star \star *}$ & $-0.0563^{* \star *}$ & $-0.0563^{* * *}$ & $-0.0767^{\star \star *}$ & $-0.0767^{\star \star \star}$ & $-0.0432^{* \star \star}$ & $-0.0432^{* * *}$ \\
\hline & $"(0.00258)$ & "(0.00180) & $"(0.00221)$ & $(0.00136)$ & $(0.00253)$ & )$^{\prime}(0.00174)$ & $(0.00332)$ & $"(0.00219)$ & $(0.00414)$ & ) ${ }^{\prime}(0.00269)$ & ' $(0.00330)$ & $"(0.00234)$ & $(0.00291)$ & $"(0.00173)$ & "(0.00399) & $"(0.00258)$ & "(0.00288) & "(0.00189) \\
\hline Logage & $0.0414^{* \star *}$ & $0.0410^{* \star *}$ & $0.0398^{* * *}$ & $0.0397^{\star \star \star}$ & $0.0400^{* \star *}$ & $0.0397^{\star \star \star}$ & $0.0459^{* * *}$ & $0.0459^{* \star \star}$ & $0.0208^{* * *}$ & ${ }^{*} 0.0230^{* * *}$ & $0.0453^{\star \star \star}$ & $0.0447^{* * *}$ & $0.00491^{* * *}$ & $0.00491^{* \star \star}$ & $-0.0167^{\star \star *}$ & $-0.0167^{\star \star \star}$ & $0.00503^{* * *}$ & ${ }^{*} 0.00503^{\star \star \star}$ \\
\hline & $'(0.00113)$ & '(0.000882) & )'(0.000922) & (") $(0.000674)$ & ${ }^{\prime}(0.00112)$ & ' $(0.000865)$ & $(0.00150)$ & $"(0.00105)$ & $(0.00182)$ & )'(0.00122) & '(0.00148) & $"(0.00123)$ & $(0.00133)$ & '(0.000950) & $(0.00174)$ & "(0.00119) & $(0.00131)$ & $"(0.00106)$ \\
\hline Size2 & $0.203^{\star * \star}$ & $0.203^{\star \star \star}$ & $0.206^{* \star *}$ & $0.206^{* \star *}$ & $0.209^{* * *}$ & $0.209^{\star * \star}$ & $-0.0649^{* * *}$ & $-0.0656^{* * *}$ & $-0.247^{\star * \star}$ & $-0.233^{* * *}$ & $-0.0692^{* * *}$ & $-0.0702^{\star \star \star}$ & $-0.268^{* \star *}$ & $-0.268^{* * *}$ & $-0.439^{\star \star \star}$ & $-0.439^{* \star *}$ & $-0.279^{* * *}$ & $-0.279^{\star \star \star}$ \\
\hline & '(0.00248) & $(0.00149)$ & '(0.00213) & $"(0.00147)$ & $(0.00246)$ & ' $(0.00174)$ & $(0.00351)$ & $'(0.00242)$ & $(0.00377)$ & ) & $(0.00351)$ & $'(0.00240)$ & $(0.00281)$ & $(0.00179)$ & "(0.00338) & '(0.00203) & $"(0.00283)$ & $"(0.00181)$ \\
\hline Size3 & $0.297^{\star * \star}$ & $0.297^{\star \star \star}$ & $0.320^{* \star \star}$ & $0.320^{* * \star}$ & $0.309^{* * *}$ & $0.309^{* \star *}$ & $-0.0142^{* *}$ & $-0.0146^{* \star *}$ & $-0.169^{\star \star *}$ & $-0.157^{\star \star \star}$ & $-0.0182^{* *}$ & $-0.0177^{\star \star \star}$ & $-0.311^{* * *}$ & $-0.311^{* \star *}$ & $-0.476^{* * *}$ & $-0.476^{* * *}$ & $-0.326^{* * \star}$ & $-0.326^{* \star \star}$ \\
\hline & '(0.00493) & "(0.00286) & '(0.00434) & '(0.00243) & $(0.00484)$ & )$^{\prime}(0.00318)$ & $(0.00706)$ & '(0.00400) & $"(0.00728)$ & ) '(0.00452) & ' $(0.00708)$ & $"(0.00362)$ & $(0.00518)$ & $"(0.00275)$ & "(0.00596) & $"(0.00361)$ & $"(0.00521)$ & '(0.00315) \\
\hline Size4 & $0.374^{\star \star \star}$ & $0.374^{\star \star \star}$ & $0.416^{\star \star \star}$ & $0.415^{\star \star \star}$ & $0.375^{\star \star *}$ & $0.377^{\star \star \star}$ & $0.0347^{\star *}$ & $0.0340^{* \star *}$ & $-0.105^{\star \star \star}$ & $-0.0921^{* * *}$ & 0.0124 & $0.0182^{*}$ & $-0.340^{\star \star \star}$ & $-0.340^{* \star *}$ & $-0.508^{\star \star \star}$ & $-0.508^{* \star \star}$ & $-0.358^{* \star *}$ & $-0.358^{\star \star \star}$ \\
\hline & $(0.0111)$ & $(0.00602)$ & '(0.00929) & $"(0.00537)$ & $(0.0111)$ & $"(0.00723)$ & $(0.0164)$ & '(0.00911) & $(0.0179)$ & $"(0.0111)$ & $(0.0177)$ & '(0.00987) & $(0.0114)$ & $(0.00706)$ & $(0.0143)$ & '(0.00858) & $(0.0121)$ & $"(0.00698)$ \\
\hline Year FE & Yes & Yes & Yes & Yes & Yes & Yes & Yes & Yes & Yes & Yes & Yes & Yes & Yes & Yes & Yes & Yes & Yes & Yes \\
\hline Industry FE & Yes & Yes & Yes & Yes & Yes & Yes & Yes & Yes & Yes & Yes & Yes & Yes & Yes & Yes & Yes & Yes & Yes & Yes \\
\hline Obs & 430181 & 429761 & 410703 & 489658 & 490557 & 410325 & 430084 & 429761 & 497986 & 489658 & 414670 & 410325 & 429761 & 429761 & 489658 & 489658 & 410325 & 410325 \\
\hline$E L(B x)$ & -0.0417 & -0.0412 & -0.0450 & -0.0449 & -0.0505 & -0.0501 & -0.1617 & -0.1617 & -0.1949 & -0.1893 & -0.1578 & -0.1550 & -0.1257 & -0.1257 & -0.1512 & -0.1512 & -0.1104 & -0.1104 \\
\hline $\mathrm{EL}(\mathrm{Wa})$ & -0.1276 & -0.1273 & -0.1187 & -0.1185 & -0.1347 & -0.1345 & -0.1752 & -0.1751 & -0.1849 & -0.1835 & -0.1724 & -0.1711 & -0.0548 & -0.0548 & -0.0738 & -0.0738 & -0.0423 & -0.0423 \\
\hline
\end{tabular}

Notes:

Robust standard errors in parentheses for OLS. Bootstrapped standard erros for SUR.

(avg) implies that the estimations use information for the "average" employee.

(hour) implies that the estimations use hours worked instead of number of employees.

(benefits) implies that the estimations include worker's benefits in the labor cost.

$* * * \mathrm{p}<0.01, * * \mathrm{p}<0.05, * \mathrm{p}<0.1$ 
Table A(II): Robustness Checks for Growth Rates of Outcome Variables (2005-2012)

\begin{tabular}{|c|c|c|c|c|c|c|c|c|c|}
\hline VARIABLES & $\begin{array}{c}(\text { a1) } \\
\text { (avg) } \\
\Delta \text { LogULC }\end{array}$ & $\begin{array}{c}\text { (b1) } \\
\text { (hour) } \\
\Delta \text { LogULC }\end{array}$ & $\begin{array}{c}(\mathrm{c} 1) \\
\text { (benefits) } \\
\Delta \text { LogULC }\end{array}$ & $\begin{array}{c}(\text { a2) } \\
(\text { avg) } \\
\Delta \text { LogLP }\end{array}$ & $\begin{array}{c}\text { (b2) } \\
\text { (hour) } \\
\Delta \text { LogLP }\end{array}$ & $\begin{array}{c}(\mathrm{c} 2) \\
\text { (benefits) } \\
\Delta \text { LogLP }\end{array}$ & $\begin{array}{c}\text { (a3) } \\
(\text { avg) } \\
\Delta \text { LogGAP }\end{array}$ & $\begin{array}{c}\text { (b3) } \\
\text { (hour) } \\
\Delta \text { LogGAP }\end{array}$ & $\begin{array}{c}(\mathrm{c} 3) \\
\text { (benefits) } \\
\Delta \text { LogGAP }\end{array}$ \\
\hline$B x$ & $\begin{array}{c}0.00684^{\star * *} \\
(0.00195)\end{array}$ & $\begin{array}{l}0.00351^{*} \\
(0.00201)\end{array}$ & $\begin{array}{c}0.00875^{\star * *} \\
(0.00196)\end{array}$ & $\begin{array}{l}0.0120^{\star * *} \\
(0.00262)\end{array}$ & $\begin{array}{l}0.0195^{\star * *} \\
(0.00371)\end{array}$ & $\begin{array}{l}0.0277^{* * *} \\
(0.00265)\end{array}$ & $\begin{array}{l}0.00519 * * \\
(0.00243)\end{array}$ & $\begin{array}{l}0.0160^{* * *} \\
(0.00341)\end{array}$ & $\begin{array}{l}0.0189^{* * *} \\
(0.00252)\end{array}$ \\
\hline Wa & $\begin{array}{c}0.00801^{* * *} \\
(0.00139)\end{array}$ & $\begin{array}{l}0.0103^{* * *} \\
(0.00139)\end{array}$ & $\begin{array}{c}0.00997^{* * *} \\
(0.00139)\end{array}$ & $\begin{array}{l}0.00349^{* *} \\
(0.00172)\end{array}$ & $\begin{array}{l}0.00592^{* *} \\
(0.00245)\end{array}$ & $\begin{array}{c}0.00860^{* * *} \\
(0.00174)\end{array}$ & $\begin{array}{c}-0.00452^{* * *} \\
(0.00160)\end{array}$ & $\begin{array}{l}-0.00434^{*} \\
(0.00224)\end{array}$ & $\begin{array}{c}-0.00137 \\
(0.00162)\end{array}$ \\
\hline Logage & $\begin{array}{l}-0.0127^{* \star *} \\
(0.000839)\end{array}$ & $\begin{array}{l}0.00399^{* * *} \\
(0.000828)\end{array}$ & $\begin{array}{l}-0.0105^{\star \star *} \\
(0.000818)\end{array}$ & $\begin{array}{l}-0.0450^{\star * *} \\
(0.00108)\end{array}$ & $\begin{array}{l}0.0112^{* * *} \\
(0.00156)\end{array}$ & $\begin{array}{c}-0.0462^{* * *} \\
(0.00107)\end{array}$ & $\begin{array}{l}-0.0323^{\star \star *} \\
(0.000987)\end{array}$ & $\begin{array}{c}0.00724^{\star * *} \\
(0.00142)\end{array}$ & $\begin{array}{l}-0.0357^{* * *} \\
(0.000980)\end{array}$ \\
\hline Size2 & $\begin{array}{c}0.00989 * * * \\
(0.00110)\end{array}$ & $\begin{array}{l}-0.0181^{* * *} \\
(0.00121)\end{array}$ & $\begin{array}{l}0.0110^{* * *} \\
(0.00110)\end{array}$ & $\begin{array}{l}-0.0267^{* * *} \\
(0.00155)\end{array}$ & $\begin{array}{l}-0.0301^{* * *} \\
(0.00193)\end{array}$ & $\begin{array}{c}-0.0339 * * * \\
(0.00156)\end{array}$ & $\begin{array}{l}-0.0366^{\star * *} \\
(0.00138)\end{array}$ & $\begin{array}{c}-0.0119^{\star * *} \\
(0.00169)\end{array}$ & $\begin{array}{c}-0.0450^{* * *} \\
(0.00143)\end{array}$ \\
\hline Size3 & $\begin{array}{l}0.0169 * * * \\
(0.00172)\end{array}$ & $\begin{array}{c}-0.0250^{* * *} \\
(0.00210)\end{array}$ & $\begin{array}{l}0.0177^{\star * *} \\
(0.00187)\end{array}$ & $\begin{array}{l}-0.0205^{\star * *} \\
(0.00271)\end{array}$ & $\begin{array}{l}-0.0479 * * * \\
(0.00321)\end{array}$ & $\begin{array}{c}-0.0288^{* * *} \\
(0.00277)\end{array}$ & $\begin{array}{c}-0.0373^{* * *} \\
(0.00245)\end{array}$ & $\begin{array}{c}-0.0229^{* * *} \\
(0.00269)\end{array}$ & $\begin{array}{c}-0.0465^{\star * *} \\
(0.00248)\end{array}$ \\
\hline Size4 & $\begin{array}{l}0.0158^{\star \star \star} \\
(0.00440)\end{array}$ & $\begin{array}{c}-0.0251^{* * *} \\
(0.00215)\end{array}$ & $\begin{array}{l}0.0176^{* * *} \\
(0.00265)\end{array}$ & $\begin{array}{l}-0.0149^{* * *} \\
(0.00550)\end{array}$ & $\begin{array}{l}-0.0432^{\star \star *} \\
(0.00560)\end{array}$ & $\begin{array}{c}-0.0192^{* \star \star} \\
(0.00557)\end{array}$ & $\begin{array}{l}-0.0306^{* * *} \\
(0.00402)\end{array}$ & $\begin{array}{c}-0.0181^{* * *} \\
(0.00546)\end{array}$ & $\begin{array}{c}-0.0368^{* * *} \\
(0.00525)\end{array}$ \\
\hline $\begin{array}{l}\text { Year FE } \\
\text { Industry FE } \\
\text { Obs }\end{array}$ & $\begin{array}{c}\text { Yes } \\
\text { Yes } \\
244884\end{array}$ & $\begin{array}{c}\text { Yes } \\
\text { Yes } \\
289586\end{array}$ & $\begin{array}{c}\text { Yes } \\
\text { Yes } \\
228693\end{array}$ & $\begin{array}{c}\text { Yes } \\
\text { Yes } \\
244884\end{array}$ & $\begin{array}{c}\text { Yes } \\
\text { Yes } \\
289586\end{array}$ & $\begin{array}{c}\text { Yes } \\
\text { Yes } \\
228693\end{array}$ & $\begin{array}{c}\text { Yes } \\
\text { Yes } \\
244884\end{array}$ & $\begin{array}{c}\text { Yes } \\
\text { Yes } \\
289586\end{array}$ & $\begin{array}{c}\text { Yes } \\
\text { Yes } \\
228693\end{array}$ \\
\hline $\begin{array}{l}\mathrm{EL}(\mathrm{Bx}) \\
\mathrm{EL}(\mathrm{Wa})\end{array}$ & $\begin{array}{l}0.0069 \\
0.0080 \\
\end{array}$ & $\begin{array}{l}0.0035 \\
0.0103 \\
\end{array}$ & $\begin{array}{l}0.0088 \\
0.0100 \\
\end{array}$ & $\begin{array}{l}0.0121 \\
0.0035 \\
\end{array}$ & $\begin{array}{l}0.0197 \\
0.0059 \\
\end{array}$ & $\begin{array}{l}0.0281 \\
0.0086 \\
\end{array}$ & $\begin{array}{r}0.0052 \\
-0.0045 \\
\end{array}$ & $\begin{array}{c}0.0161 \\
-0.0043 \\
\end{array}$ & $\begin{array}{c}0.0191 \\
-0.0014 \\
\end{array}$ \\
\hline
\end{tabular}

Notes:

All estimations are OLS(re).

(avg) implies that the estimations use information for the "average" employee.

(hour) implies that the estimations use hours worked instead of number of employees.

(benefits) implies that the estimations include worker's benefits in the labor cost.

Robust standard errors in parentheses

${ }^{* * *} p<0.01,{ }^{* *} p<0.05,{ }^{*} p<0.1$ 